ISSN 1392-3196 / e-ISSN 2335-8947

Zemdirbyste-Agriculture, vol. 108, No. 3 (2021), p. 217-226

DOI 10.13080/z-a.2021.108.028

\title{
Barley yield estimation performed by ANN integrated with the soil quality index modified by biogas waste application
}

\author{
Pelin ALABOZ1 ${ }^{1}$, Orhan DENGIZ², Sinan DEMIR ${ }^{1}$ \\ ${ }^{1}$ Isparta University of Applied Sciences, Faculty of Agriculture \\ Isparta, Turkey \\ E-mail: pelinalaboz@isparta.edu.tr \\ ${ }^{2}$ Ondokuz Mayıs University, Faculty of Agriculture \\ Samsun, Turkey
}

\begin{abstract}
Today, the evaluation of soil quality and crop yield has become a critical issue in meeting the increasing population's food needs. The current study aims to analyse and predict the effect of biogas waste (BW) application on soil quality and barley yield. The yield of barley grown in the soil with 0 (B0), 10 (B1), 20 (B2), 30 (B3) and 40 (B4) $\mathrm{t} \mathrm{ha}^{-1} \mathrm{BW}$ applied and the physical, chemical and biological properties of the soil were examined. In determining the soil quality index (SQI), the analytic hierarchy process and linear combination technique were used, 27 soil indicators in the total data set (TDS) and 10 soil indicators were evaluated separately due to the minimum data set (MDS) created with a principal component analysis (PCA). The relationship between SQI values obtained based on application and barley yield was estimated by applying general regression equations and Levenberg-Marquardt training algorithm in artificial neural networks (ANN).

The quality of soil, which was the II class, at the $0 \mathrm{t} \mathrm{ha}^{-1}$ (control) BW for both data sets with biogas waste application was defined as the III and IV soil quality classes. While the increases in barley crop yield were similar to the soil quality index values obtained with the MDS (SQI ${ }_{M D S}$ ), the optimum yield was obtained at the $30 \mathrm{t} \mathrm{ha}^{-1}$ $\mathrm{BW}$; with this application, an increase of $35.62 \%$ barley crop yield was achieved compared to the $0 \mathrm{t}$ ha ${ }^{-1} \mathrm{BW}$. For both data sets, the coefficient of determination $\left(R^{2}\right)$ by general regression in the yield estimates from the SQI had a prediction accuracy of $0.87-0.88$. At the same time, the values in ANN were determined as $0.91-0.92$. Among the estimation methods, the highest $R^{2}$, low root mean square error (RMSE) - $125.5 \mathrm{~kg}$ and Akaike information criterion (AIC) - 359.58 were determined by ANN.

The study concluded that biogas waste application increases soil quality and barley yield. The MDS can be adopted successfully in soil quality determination, and the barley crop yield can be predicted with high accuracy from the soil quality with ANN.
\end{abstract}

Key words: biogas waste, minimum data set, artificial neural networks, soil quality, analytical hierarchical process, Akaike information criterion.

\section{Introduction}

In the natural ecosystem cycle, soil, water and air quality are crucial for natural resource sustainability. Soil quality is a complex indicator that is evaluated as a result of the effect of physical, chemical and biological parameters according to air and water quality. The soil quality, which has a three-phase and complex structure, is a dynamic combination of physical, chemical and biological processes. Besides, soil quality external affect factors such as climate and topography (Bünemann et al., 2018). Soil quality, which was first stated to be the yield potential of soils under good management, was also defined by Doran and Parkin (1994), as the capacity of soil within a natural or managed ecosystem to sustain vegetative and animal production, increase water and air quality and provide a suitable living environment for human health.
In recent years, the increasing demand and pressure of the population for natural resources, unconscious and incorrect land use and variations of climate conditions have caused land degradation. Consequently, soil quality indicators are also widely investigated in the field and environmental risk assessment studies (Hurni et al., 2015). Evaluating land and soil quality together is vital for sustainable agriculture. Many studies are using Cornel Soil Health Assessment (CSHA) and Soil Management Assessment Framework (SMAF) score functions or linear combination technique from parametric methods as quantitative methods for evaluating soil quality (Mukherjee, Lal, 2014; Şeker et al., 2017; Şenol et al., 2019; Dengiz, 2020). In these studies, physical, chemical and biological processes of

Please use the following format when citing the article:

Alaboz P., Dengiz O., Demir S. 2021. Barley yield estimation performed by ANN integrated with the soil quality index modified by biogas waste application. Zemdirbyste-Agriculture, 108 (3): 217-226. DOI 10.13080/z-a.2021.108.028 
soils are handled together. Again, the most critical factor of both approaches is to test the obtained soil quality index values through yield values. Still, this may not always be possible through field trials or field studies.

Therefore, estimation modelling is also required. With the developing technology in modelling studies known as pedotransfer functions, artificial neural networks (ANN) are increasing day by day. Tavanti et al. (2019) determined the lowest root mean square error (RMSE) $\left(0.0142 \mathrm{~m}^{3} \mathrm{~m}^{-3}\right)$ and mean absolute percentage error (MAPE) $\left(0.0018 \mathrm{~m}^{3} \mathrm{~m}^{-3}\right)$ with ANN in their estimates of moisture constants. Moreover, Ghorbani et al. (2017) predicted field capacity and wilting point best with ANN and support vector machine. Today, different machine learning algorithms and other estimation methods are widely used in estimating soil properties and high predictive accuracy can be obtained (Yamaç et al., 2020).

Although the number of indicators in the data set increases the linearity in estimating quality, the cost and labour requirements also increase. For this purpose, the minimum data set is formed by removing the features with a high correlation from the data set. In the study, where the selection of 11 quality indicators on average was stated by Bünemann et al. (2018), it was suggested that at least one feature from the physical, chemical and biological indicator groups should be in the data set, while evaluating soil quality many criteria should be regarded together. Also, determining the weights and the scores of the sub-criteria were deemed a more effective approach in predicting the desired feature, since the affecting standards are not at the same level of importance. Thus, one of the multi-criteria decision-making methods - the analytic hierarchy process - has been widely applied in evaluating the soil and its complex structure (Demirağ Turan, Dengiz, 2017).

In evaluating soil quality, the most investigated properties are nutrient elements, organic matter and hydraulic properties (Watzinger, 2015). According to the literature, there are positive increases in productivity parameters with the addition of organic matter. Masto et al. (2007) reported that the dehydrogenase and alkaline phosphatase activities, water-soluble and microbial biomass carbon $(\mathrm{C})$ and nitrogen $(\mathrm{N})$ levels increased significantly with the co-application of chemical fertilizers and farmyard manure. Ai et al. (2020) stated that soil quality improves compost and green manure applications. Stable aggregates increase with organic material, slow decomposing organic matter forms stable aggregates effective in aggregation, and these contain high levels of carbon (Nesic et al., 2014). Besides, its positive effect on water retention due to its fibrous structure points out that organic matter is crucial in evaluating soil quality (Alaboz, Öz, 2020). Many organic materials are applied as sources of nutrients or soil conditioners resulting from decomposition.

In recent years, it has been possible to get energy by producing biogas from organic wastes of plant and animal origin and obtaining fertilisers with nutritional value in the form of by-products. Biogas waste practices improve the physical, chemical and biological properties of soils by increasing soil organic matter. The literature (Abubaker et al., 2012) has stated that it causes increases in plant yield. Still, very few studies validate biogas waste effect on soil quality indicators and yield and the ANN yield estimation model with field trial experiment.

The objectives of this study were as follows: (i) to examine the physical, chemical and biological soil indicators and barley yield changes due to the biogas waste application; (ii) to select indicators with minimum data set (MDS) and evaluate the effect of applications on soil quality with analytic hierarchy process and linear combination technique; (iii) to analyse the relationship between soil quality and barley yield by artificial neural networks (ANN) and general regression.

\section{Materials and methods}

Description of the study area. The experiment was conducted in the practice farm of Isparta University of Applied Sciences (WGS 1984 UTM Zone 36N 283100$282921 \mathrm{~N}$ and 4190355-4191399 E), Turkey (Figure 1). There are orchards, vineyards and nurseries in the area, where dry agriculture is generally dominant. The farmland is located on a colluvial soil with a flat slope on a depression surrounded by high hills and ridges in other directions opening to the Isparta plain in the south-east direction.

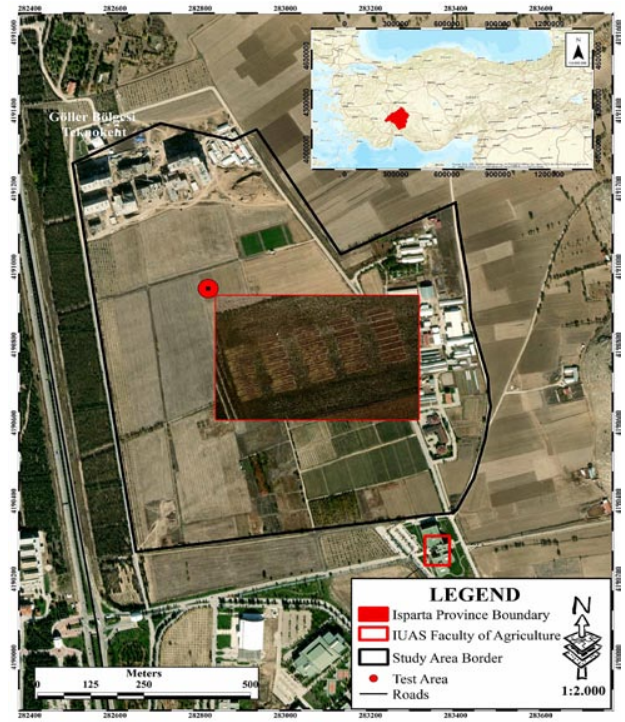

Figure 1. Location map of the experimental area

The general geological structure of the experimental area - the hilly regions around are composed of cretaceous limestones. The flat area where the experiment was established shows a distribution of soils formed on quaternary colluvial deposits from the quaternary period (Şenol et al., 2020). According to the area's meteorological data for many years, the average annual precipitation is $540.1 \mathrm{~mm}$ and the average annual temperature $-12.3^{\circ} \mathrm{C}$; the soil temperature and humidity regimes are Mesic and Dry Xeric (Van Wambeke, 2000). Application of biogas waste $(B W)$ in the field experiment. In the experiment carried out according to the randomized block design, $\mathrm{BW}$ as organic material was obtained from the biogas production facility. During the biogas production stage, farmyard manure was used and the organic waste material extracted from the final product; the separator press with approximately $15 \%$ moisture was used. BW was applied at rates of $0(\mathrm{~B} 0), 10$ (B1), 20 (B2), 30 (B3) and 40 (B4) tha ${ }^{-1}$ to $3 \times 5 \mathrm{~m}^{2}$ plots with 5 replications.

At planting time, the seedbed was prepared with a rotary tiller in the experimental area ploughed with a plough (Kurt Tarım, Turkey). In the experiment established on 19 November, 2019, after the biogas waste was mixed to an approximately $0-20 \mathrm{~cm}$ depth, two rows of barley (Hordeum vulgare L.) cultivar 'Agriculture-92' were planted with a 6-row automatic piston seeder (Kurt Tarım, Turkey). As the basic fertiliser, $100 \mathrm{~kg} \mathrm{ha}^{-1} \mathrm{~N}$ and $80 \mathrm{~kg} \mathrm{ha}^{-1} \mathrm{~K}$ were applied, and the trial was harvested on 5 July, 2020. The barley yield was calculated for square meter. The organic material content of the biogas waste was $46.7 \%$. The biogas waste had a $\mathrm{pH}$ value of 7.70 , and its $\mathrm{C}$ to $\mathrm{N}$ ratio was 12.1 . The $\mathrm{P}$ and $\mathrm{K}$ contents of the material were $0.84 \%$ and $0.75 \%$, while the $\mathrm{Cu}, \mathrm{Zn} \mathrm{Mn}$ and Fe contents were 15.8, 35, 109 and 859 ppm, respectively. Soil sampling and analysis. Before the harvest, three parallel disturbed and undisturbed soil samples were taken from each application's repetition and brought to the laboratory. Preliminary preparations were carried out for soil analysis. The textural fraction distribution of soil 
samples was determined using the hydrometer method (Bouyoucos, 1951). Lime content was determined using a Scheibler calcimeter (Burt, 2014), dry bulk density and soil porosity were determined by undisturbed sampling according to Burt (2014). Electrical conductivity (EC) and soil acidity $(\mathrm{pH})$ values and applied material were measured in 1:1 soil-water and 1:5 organic material-water suspension. Organic matter (OM) content was determined by the modified Walkley-Black and dry burning method (Burt, 2014). Field capacity and wilting point of the soil samples were determined by volume with the help of a ceramic table $\mathrm{pF}$ set (Soil Moisture Equipment Corp., USA). The available water capacity (AWC) was defined as the moisture content between field capacity and the wilting point (Burt, 2014). Penetration resistance measurements were performed with a penetrologger using a cone, $60^{\circ}$ and a cone-shaped tip with a base area of $1 \mathrm{~cm}^{2}$. Moisture corrections in the penetration resistance value were made using the correction equation specified by Alaboz and Öz (2020). $\mathrm{Ca}, \mathrm{Mg}, \mathrm{K}$ and $\mathrm{Na}$ contents were determined by extracting with $1 \mathrm{~N}$ ammonium acetate (NH OAc) using an atomic absorption spectroscopy device (Burt, 2014), total nitrogen $(\mathrm{N})$ - according to the modified Kjeldahl method; micronutrients $\mathrm{Fe}, \mathrm{Mn}, \mathrm{Cu}$ and $\mathrm{Zn}$ contents were determined according to the method of extraction with DTPA useful phosphorus according to Carter and Gregorich (2007). Aggregation percentages were calculated according to Richards (2012).

From the biological analysis, urease enzyme activity was determined according to Tabatabai and Bremner (1972), and soil respiration was determined by the reaction of barium hydroxide $\left(\mathrm{Ba}(\mathrm{OH})_{2}\right)$ with $\mathrm{CO}_{2}$ from the soil and the titration of the remaining $\mathrm{Ba}(\mathrm{OH})_{2}$ with hydrochloric acid $(\mathrm{HCl})$ solution (Isermayer, 1952). In the dehydrogenase group enzyme analysis, the spectrophotometrical determination of the colour resulting from the conversion of 2-, 3- and 5-triphenyltetrazolium chloride (TTC) to triphenyl formazan (TPF) per unit time was used (Beyer et al., 1993).

Determination of soil quality using the standard scoring function and analytic hierarchy process (AHP) approach. In the experiment, 27 soil indicators were used. Since each soil indicator has different units, they were converted into unitless form by applying the standard scoring function as the first step. Afterward, to determine effect levels of soil quality indicators, the indicators were weighted with the AHP developed by Saaty (2001). In the first step, soil quality indicators were transformed into unitless scores between 0.1 and 1.0 to be comparable using standard scoring functions (Mukherjee, Lal, 2014). In general, three standard scoring functions (SSF) are used: "more is better", "less is better" and "the midpoint is optimum" (Tongsiri etal. 2020). The SSF equations for the parameters are listed in Table 1. When the change intervals of soil quality indicators obtained for the experimental area were examined, no feature was found suitable to use "midpoint is optimum" function. So, in line with the values obtained in the experiment, "less is better" (eq. 1) and "more is better" (eq. 2) approaches were used. In the "more is better" function, $\mathrm{OM}, \mathrm{N}, \mathrm{P}, \mathrm{Ca}, \mathrm{Mg}, \mathrm{Fe}, \mathrm{Cu}, \mathrm{Zn}$ and $\mathrm{Mn}$ contents, field capacity, available water capacity, aggregation, $\mathrm{CO}_{2}$, urease, dehydrogenase, clay and soil porosity were taken, while in the "less is better" approach sand, silt, EC, calcium carbonate $\left(\mathrm{CaCO}_{3}\right)$, bulk density, wilting point, $\mathrm{pH}$, penetration resistance and $\mathrm{Na}$ content were taken.

With the AHP method, it is possible to compare qualitative and quantitative factors and determine their weights and priorities. Numerical values indicating their relative importance of soil properties to each other were evaluated according to the Saaty (2001) scale: a comparison evaluating the severity range from 1 to 9 . Binary comparison is applied to criteria and sub-criteria according to expert opinions and evaluations.

Table 1. Soil quantitative parameters and standard scoring function (SSF)

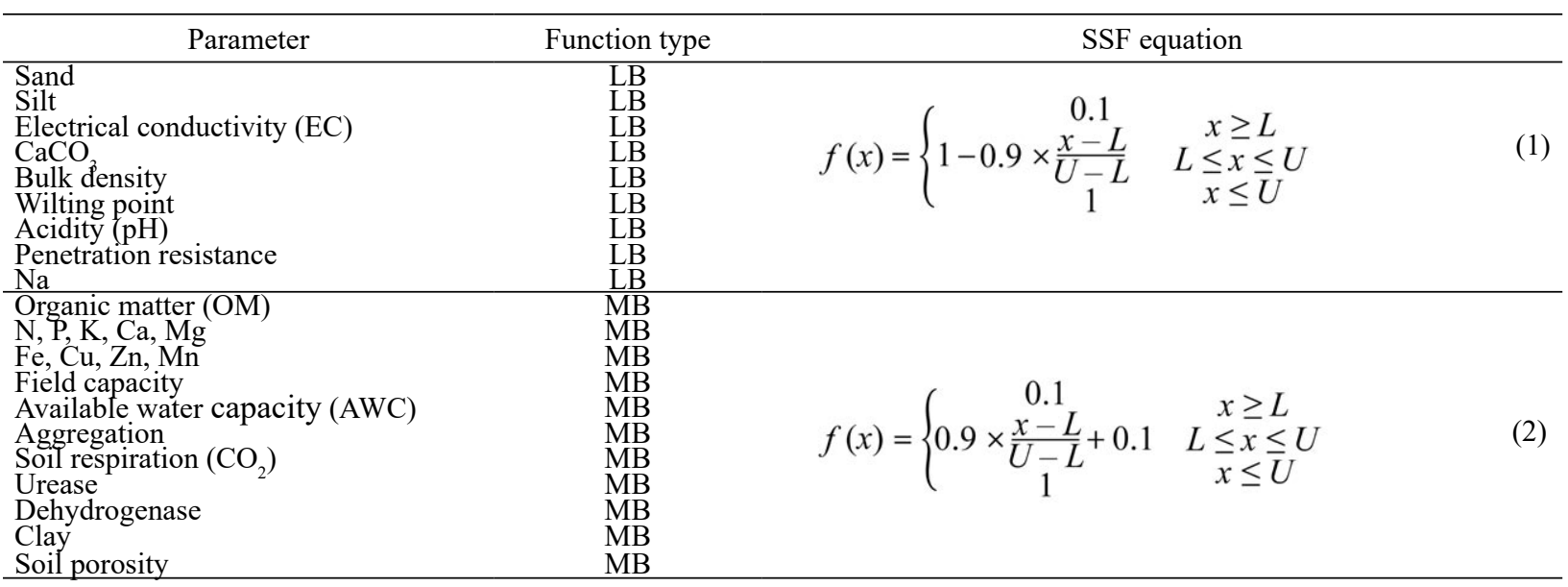

Note. MB - more is better, $\mathrm{LB}-$ low is better; $\mathrm{L}$ and $\mathrm{U}$ are the lower and the upper threshold value, respectively.

A comparison matrix $(\mathrm{n} \times \mathrm{n}$ dimensions $)$ is created between criteria considering the criteria' importance. All entries in this created matrix must have positive values: A - binary comparison matrix aij; the importance of element $i$ relative to element $J(i, J \ldots n)$. Properties of binary comparison matrix: aji $=1 /$ aij; aij $>0(i, j=1,2, \ldots n)$; for the binary comparison to being fully consistent: $a_{i j}=a_{i k} a_{i k}(i, j, k=1,2, \ldots n)$, if consistent $a_{i j}=W_{i} / W_{j}$, where $W_{i}^{i k}$ is priority value for element $i, W_{j}$ - priority value for element $\mathrm{J}$.

After the comparison matrix is created, the normalization of the matrix is performed. The normalization process is performed by dividing the data in each cell by the column total. By taking the arithmetic mean of the sum of the data in each row in the normalization table obtained from binary comparisons, the $\mathrm{W}$ column vector, called the priority vector, is received. This vector expresses the percent weight of the criteria.

The binary comparison matrix (A) is multiplied by the priority vector (W) to obtain the vector $\mathrm{D}$. The elements of the $\mathrm{D}$ column vector $\left(\mathrm{d}_{1}=\mathrm{a}_{11} \times \mathrm{w}_{1}+\mathrm{a}_{12} \times \mathrm{w}_{2} \ldots\right.$ $\mathrm{a}_{1 \mathrm{n}} \times \mathrm{w}_{\mathrm{n}}$ ) are divided by the elements of the priority vector (W) to obtain the E values. The sum of the E. values is divided by the number of criteria, and its arithmetic average is calculated. With this operation, $\lambda$ the largest eigenvalue of the matrix called $\max$ is found. The eigenvector method is used to measure the consistency in comparisons, and the consistency index (CI) is obtained. The consistency ratio (CR) value is obtained by dividing the consistency index (CI) by the random index (RI). The CR value of less than 0.10 indicates that the decision-makers' comparisons are consistent, and a CR 
value greater than 0.10 suggests that the comparisons are inconsistent or there are calculation errors. In this case, the comparisons should be reviewed (Saaty, 2001).

After the properties weighted by analytic hierarchy process (AHP) were standardized with standard scoring function (SSF), soil quality index (SQI) values were determined using the linear combination technique approach (Dengiz, 2020) (eq. 3) and classified in Table 2:

$$
\mathrm{SQI}=\sum_{\mathrm{i}=1}^{\mathrm{n}}(\mathrm{Wi} \times \mathrm{Xi})
$$

where SQI is soil quality index for agricultural usage, Wi - weighting of parameter $\mathrm{i}, \mathrm{Xi}$ - sub-criterion score of parameter $i$. The above formula was applied to each soil sample.

Table 2. Classes of soil quality index (SQI)
Artificial neural networks (ANN) model. To evaluate soil quality and crop yield relationships, the general regression equation and ANN were used. Structures resembling human nerve cells come together to form an ANN. In an ANN cell, there are inputs ( $X_{1}$, $\mathrm{X}_{2}$ and $\left.\mathrm{X}_{\mathrm{i}}\right)$, weights $\left(\mathrm{W}_{1}, \mathrm{~W}_{2}\right.$ and $\left.\mathrm{W}_{\mathrm{i}}\right)$, addition function, activation function and outputs (Y) (Figure 2).

Usually, a net variable (NET) is defined. NET (eq. 4) input value is obtained by multiplying the inputs with the weights and bias (C) (Graupe, 2013):

$$
\mathrm{NET}=\sum_{\mathrm{i}=1}^{\mathrm{n}} \mathrm{Xi} \times \mathrm{Wi}+\mathrm{C}
$$

NET value is processed with the activation function, and the output to be produced by the network

\begin{tabular}{ccc}
\hline Class & Definition & SQI \\
\hline I & very low & $<0.40$ \\
II & low & $0.40-0.50$ \\
III & moderate & $0.50-0.65$ \\
IV & high & $0.65-0.85$ \\
V & very high & $>0.85$ \\
\hline
\end{tabular}

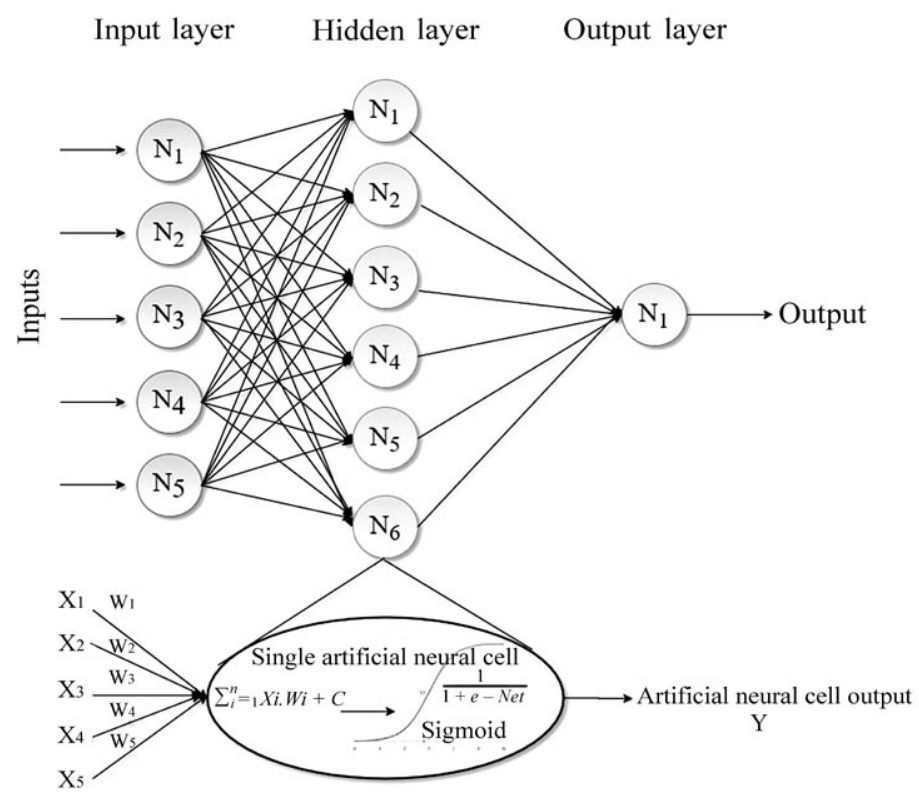

Figure 2. Functional structure of artificial neural networks (ANN) $\sum$

is determined. The relevant layer is output and given as input to the next layer by applying the activation function. One of the most used activation functions is the sigmoid function (Graupe, 2013).

In the connection between neurons, information is in unidirectional ordered layers from entry to exit. In the feed-forward network, nerve cells are treated in layers called the input, hidden and output layers (Figure 2). In this study, the sigmoid is used as the activation function studied with multi-layer feed-forward backpropagation networks (eq. 5):

$$
\mathrm{f}(\mathrm{NET})=\frac{1}{1+\mathrm{e}^{-\mathrm{NET}}}
$$

As the training algorithm, Levenberg-Marquardt was used; $60 \%$ of the data set was used as training, $20 \%$ as test and $20 \%$ as verification. To assess the relationships between observed and predicted values, the determination coefficient $\left(R^{2}\right)$, the root mean square error (RMSE) and the Akaike information criterion (AIC) that evaluates the likelihood function in the observation data were used (Shi et al., 2015; Wang et al., 2015) (eq. 6-8):

$$
R^{2}=\left[\frac{\sum \mathrm{ZiZ}-\frac{\sum \mathrm{Zi} \sum \mathrm{Z}}{\mathrm{n}}}{\left.\sqrt{\left[\sum \mathrm{Zi}^{2}-\frac{\left(\sum Z i\right)^{2}}{n}\right]\left[\sum Z^{2}-\frac{\left(\sum Z\right)^{2}}{n}\right.}\right]}\right]
$$

$$
\begin{aligned}
& \mathrm{RMSE}=\sqrt{\frac{\sum(\mathrm{Zi}-\mathrm{Z})^{2}}{\mathrm{n}}} \\
& \mathrm{AIC}=\mathrm{n} \log \left(\frac{R S S}{n}\right)+2 k
\end{aligned}
$$

where $\mathrm{Zi}$ is predictive value, $\mathrm{Z}$ - observed value, $\mathrm{n}$ - number of observations, $\mathrm{k}$ - number of parameters used in the model, RSS - a residual sum of squares.

Statistical analysis. The principal component analysis (PCA) and multiple comparison test (Tukey) were determined through statistical software SPSS, version 23 (IBM Inc., USA). In the PCA, soil properties were standardized, and Kaiser-Meyer-Olkin (KMO) and Bartlett sphericity test results were examined. The suitability of the data for factor analysis was checked. The basic component up to the eigenvalue greater than 1 was selected; the minimum data set (MDS) was created by examining the correlation matrix (Pearson). For estimation with artificial neural networks (ANN), package program MATLAB (The MathWorks Inc., USA) was applied. 


\section{Results and discussions}

The effect of biogas waste $(B W)$ application on soil and barley yield. The effect of the BW application on soil properties and yield is given in Table 3 . The soil contained $36.7 \%$ clay, $35.2 \%$ silt and $28.1 \%$ sand and had a clay loam texture. Bulk density decreased depending on the organic matter (OM) content. The increase in soil porosity with $\mathrm{OM}$ application caused significant decreases $(P<0.01)$ in bulk density and penetration resistance. Similar changes were found by Alaboz and Öz (2020) and Müjdeci et al. (2020).

While the field capacity at the $0 \mathrm{tha}^{-1} \mathrm{BW}$ was $0.28 \mathrm{~cm} \mathrm{~cm}^{-3}$, an increase of approximately $39 \%$ was achieved at the 30 and $40 \mathrm{t} \mathrm{ha}^{-1} \mathrm{BW}$. In the wilting point, the applications' effect was similar up to the $40 \mathrm{t} \mathrm{ha}^{-1} \mathrm{BW}$; the $40 \mathrm{t} \mathrm{ha}^{-1} \mathrm{BW}$ showed a significant change $(P<0.01)$ compared to the other applications. The moisture level in field capacity is positively affected by soil porosity, and the wilting point often varies depending on the clay content and type. Stability of the wilting point until $40 \mathrm{t}$ $\mathrm{ha}^{-1} \mathrm{BW}$ caused an increase in available water capacity, while the rise in wilting point at the $40 \mathrm{tha}^{-1} \mathrm{BW}$ decreased one. Biogas waste application increased the number of pores in the soil that allowed water retention. The use of water by the plant increased by decreasing the retention energy of water with B1, B2 and B3 applications. The addition of $\mathrm{OM}$ increases the available water capacity at higher tensions by increasing the surface area (Gliński et al., 2011). When the effect of the applications on the aggregation rate was examined, the aggregation rate, which was $72.45 \%$ at the $0 \mathrm{t} \mathrm{ha}^{-1} \mathrm{BW}$, showed a significant increase $(P<0.01)$ of approximately $4 \%$ at the 10 and

Table 3. Effect of biogas waste application on soil properties and barley yield

\begin{tabular}{|c|c|c|c|c|c|c|c|c|c|c|c|}
\hline Parameter & $\mathrm{B} 0$ & B1 & $\mathrm{B} 2$ & B3 & B4 & Parameter & B0 & B1 & $\mathrm{B} 2$ & B3 & B4 \\
\hline Clay $\%$ & & & 36.7 & & & $\mathrm{~N} \%$ & $0.105 \mathrm{e}^{*}$ & $0.123 \mathrm{~d}$ & $0.141 \mathrm{c}$ & $0.162 \mathrm{~b}$ & $0.172 \mathrm{a}$ \\
\hline Silt \% & & & 35.2 & & & P mg kg-1 & $4.5 c^{*}$ & $12 \mathrm{~b}$ & $13 \mathrm{~b}$ & $31 \mathrm{a}$ & $30 \mathrm{a}$ \\
\hline Sand $\%$ & & & 28.1 & & & $\mathrm{~K} \mathrm{mg} \mathrm{kg}^{-1}$ & 350 & 362 & 358 & 383 & 369 \\
\hline Bulk density $\mathrm{g} \mathrm{cm}^{-3}$ & $1.46 \mathrm{a}^{*}$ & $1.35 \mathrm{~b}$ & $1.29 \mathrm{c}$ & $1.22 \mathrm{~d}$ & $1.20 \mathrm{~d}$ & Ca mg kg-1 & $3900 \mathrm{~d}^{*}$ & $4170 \mathrm{a}$ & $4160 \mathrm{a}$ & $4000 \mathrm{c}$ & $4070 \mathrm{~b}$ \\
\hline Penetration resistance $\mathrm{MPa}$ & $1.56 \mathrm{a}^{*}$ & $1.37 \mathrm{~b}$ & $1.30 \mathrm{c}$ & $1.28 \mathrm{c}$ & $1.22 \mathrm{~d}$ & $\mathrm{Mg} \mathrm{mg} \mathrm{kg}^{-1}$ & 185 & 192 & 191 & 242 & 256 \\
\hline Soil porosity \% & $0.54 \mathrm{c}^{*}$ & $0.54 \mathrm{c}$ & $0.57 \mathrm{~b}$ & $0.62 \mathrm{a}$ & $0.61 \mathrm{a}$ & $\mathrm{Na} m g \mathrm{~kg}^{-1}$ & 2.37 & 2.21 & 2.42 & 2.37 & 2.41 \\
\hline Aggregation & $72.45 \mathrm{c}^{*}$ & $75.38 \mathrm{~b}$ & $76.35 \mathrm{~b}$ & $77.45 \mathrm{a}$ & $77.32 \mathrm{a}$ & Fe mg kg-1 & $5.21 \mathrm{c}^{*}$ & $5.00 \mathrm{~d}$ & $5.21 \mathrm{c}$ & $6.81 \mathrm{~b}$ & $8.01 \mathrm{a}$ \\
\hline Field capacity $\mathrm{cm}^{3} \mathrm{~cm}^{-3}$ & $0.28 \mathrm{c}^{*}$ & $0.29 \mathrm{bc}$ & $0.33 \mathrm{~b}$ & $0.39 \mathrm{a}$ & $0.38 \mathrm{a}$ & $\mathrm{Cu} \mathrm{mg} \mathrm{kg}{ }^{-1}$ & 7.52 & 7.50 & 7.62 & 7.64 & 7.64 \\
\hline Wilting point $\mathrm{cm}^{3} \mathrm{~cm}^{-3}$ & $0.18 \mathrm{~b}$ & $0.18 \mathrm{~b}$ & $0.19 \mathrm{~b}$ & $0.19 \mathrm{~b}$ & $0.23 \mathrm{a}$ & $\mathrm{Zn} \mathrm{mg} \mathrm{kg}{ }^{-1}$ & $1.24 \mathrm{~d}^{*}$ & $1.35 \mathrm{c}$ & $1.48 \mathrm{~b}$ & $1.57 \mathrm{a}$ & $1.60 \mathrm{a}$ \\
\hline $\begin{array}{l}\text { Available water capacity } \\
\text { (AWC) } \mathrm{cm}^{3} \mathrm{~cm}^{-3}\end{array}$ & $0.10 \mathrm{c}$ & $0.11 \mathrm{c}$ & $0.14 \mathrm{bc}$ & $0.20 \mathrm{a}$ & $0.15 \mathrm{~b}$ & Mn mg kg-1 & $16.45 \mathrm{c}^{*}$ & 18.01 & 8.6 & 8.9 & 0.2 \\
\hline Acidity $(\mathrm{pH})$ & 7.87 & 7.85 & 7.87 & 7.88 & 7.90 & $\begin{array}{l}\mathrm{CO}_{2} 100 \mathrm{~g} \\
\text { dry soil }^{-1} 24 \mathrm{~h}^{-1}\end{array}$ & $25.32 \mathrm{c}^{*}$ & 32.45 & 5.78 & 5.37 & $5.34 \mathrm{a}$ \\
\hline $\begin{array}{l}\text { Electrical conductivity (EC) } \\
\mathrm{dS} \mathrm{m}^{-1}\end{array}$ & $0.38 \mathrm{~d}^{*}$ & $0.41 \mathrm{c}$ & $0.42 \mathrm{c}$ & $0.43 \mathrm{~b}$ & $0.44 \mathrm{a}$ & $\begin{array}{l}\text { Urease N g } \\
\text { dry soil }{ }^{-1}\end{array}$ & $35.43 \mathrm{c}^{*}$ & 39.48 & 8.7 & 38 & 3.75 \\
\hline $\mathrm{CaCO}_{3} \%$ & 25.43 & 25.75 & 26.89 & 26.98 & 27.31 & $\begin{array}{l}\text { Dehydrogenase } \\
\mu \mathrm{g} \text { TPF g } \\
\text { dry soil }{ }^{-1}\end{array}$ & 3.45 & 3.44 & 3.78 & 3.84 & 3.80 \\
\hline Organic matter $(\mathrm{OM}) \%$ & $1.69 \mathrm{e}^{*}$ & $2.03 \mathrm{~d}$ & $2.47 \mathrm{c}$ & $2.89 \mathrm{~b}$ & $2.97 \mathrm{a}$ & Yield kg ha ${ }^{-1}$ & $4940 \mathrm{~d}^{*}$ & $5420 \mathrm{c}$ & $5790 \mathrm{~b}$ & $6700 \mathrm{a}$ & $6630 \mathrm{a}$ \\
\hline
\end{tabular}

Note. Biogas (B) waste: B0 - $0 \mathrm{t} \mathrm{ha}^{-1}$ (control), B1 - $10 \mathrm{t} \mathrm{ha}^{-1}, \mathrm{~B} 2-20 \mathrm{t} \mathrm{ha}^{-1}, \mathrm{~B} 3-30 \mathrm{t} \mathrm{ha}^{-1}, \mathrm{~B} 4-40 \mathrm{t} \mathrm{ha}^{-1}$; * significant differences at $p<0.01$ level between values that are not represented by the same letter.

$20 \mathrm{tha}^{-1} \mathrm{BW}$ and $5 \%$ at the 30 and $40 \mathrm{t} \mathrm{ha}^{-1} \mathrm{BW}$. Humic substances resulting from the breakdown of $\mathrm{OM}$ increase aggregation by causing flocculation between molecules (Plaster, 2013)

The salt content of the soil, which was $0.38 \mathrm{dS} \mathrm{m}^{-1}$ at the $0 \mathrm{t} \mathrm{ha}^{-1} \mathrm{BW}$, increased statistically depending on the applications but did not cause salinity problems. Since the EC content of the biogas waste was high, the EC content of the soil increased. According to Hazelton and Murpy (2016), the soils are very calcareous. The applications did not have a significant effect on $\mathrm{CaCO}_{3}$ and $\mathrm{pH}$ Although these properties are not regular depending on the application, they have shown an increasing tendency. It was determined that dissolved organic compounds and $\mathrm{CaCO}$ minerals on the surface interact, and the balance between solution and solid phase is affected. Besides, it is known that the $\mathrm{pH}$ level may first increase as a result of the organic material decomposition (Plaster, 2013).

According to FAO (2006) and Hazelton and Murpy (2016), the P content of the control soil (B0) was determined as "insufficient", $\mathrm{N}, \mathrm{K}, \mathrm{Mg}, \mathrm{Cu}, \mathrm{Zn}$ and $\mathrm{Mn}$ contents were determined as "sufficient", and $\mathrm{Fe}$ and $\mathrm{Ca}$ contents were determined as "excess". The most significant increase in the effect of biogas waste application on macronutrients was determined in $\mathrm{P}$ content. Phosphorus content, which was determined at an insufficient level at the $0 \mathrm{t} \mathrm{ha}^{-1} \mathrm{BW}$, increased to "sufficientexcess" levels depending on the increase in applications. When the $\mathrm{CO}_{2}$ emerging during the decomposition of $\mathrm{OM}$ dissolves in water, carbonic acid $\left(\mathrm{H}_{2} \mathrm{CO}_{3}\right)$ is formed. The $\mathrm{H}_{2} \mathrm{CO}_{3}$ created plays a significant role in releasing $\mathrm{P}$ in calcareous soils. It has been reported that the degradation products of OM turn into phospho-humic compounds in calcareous-alkaline soils, and thus the availability of $\mathrm{P}$ increases by becoming independent of the phosphate ions with the replacement of humate and phosphate anions (Plaster, 2013). Similarly, the Fe content at the $40 \mathrm{t} \mathrm{ha}^{-1}$ $\mathrm{BW}$ in the microelement provided a significant increase $(P<0.01)$ at approximately $53 \%$ compared to the $0 \mathrm{t} \mathrm{ha}^{-1}$ BW. Depending on the applications, no significant changes were determined in the $\mathrm{K}, \mathrm{Mg}, \mathrm{Na}$ and $\mathrm{Cu}$ contents. The elements in question showed an increasing trend due to increasing doses in general.

The type and number of microorganisms present in the soil are crucial characteristics evaluated as indicators of soil fertility. According to the $\mathrm{CO}_{2}$ output results obtained in the classification made by USDA (2020, https://www.nrcs.usda.gov/Internet/ FSE DOCUMENTS/nrcs142p2 053267.pdf) in the B0, low soil activity $\left(25.32 \mathrm{mg} \mathrm{CO} 100 \mathrm{~g}^{2}\right.$ dry soil $\left.{ }^{-1} 24 \mathrm{~h}^{-1}\right)$ was determined in the experiment. According to Hofmann and Hoffmann (1966), urease activity was determined to be low (35.43-43.85 $\mu \mathrm{g} \mathrm{g}^{-1} \mathrm{~N}$ dry soil); there was an increase in the values of biological indicators, depending on the applications. The dehydrogenase enzyme, which is one of the fundamental indicators of biological activity and is responsible for realizing soil respiration, and the urease enzyme produced by living cells in the breakdown phase of OM and the $\mathrm{N}$ cycle, are also crucial. Microbial decomposition products facilitate the formation of clayorganic complexes. Also, the increase in microbial activity increases fragmentation and decomposition of OM (Ekberli, Dengiz, 2016).

Assessment of the indicator weighted with analytic hierarchy process (AHP) for minimum data set (MDS). The results of the PCA was estimated to be 
four main components with an eigenvalue $>1$, and the variance explained at $81.467 \%$ (Table 4 ).

There are 27 indicators in the total data set (TDS). A MDS was created according to the PCA. After PCA, 10 soil indicators were selected in MDS: clay, bulk density, penetration resistance, soil porosity, field capacity, available water capacity, EC, OM, N, P, K, Mg, $\mathrm{Fe}, \mathrm{Zn}$ and $\mathrm{CO}_{2}$ in $\mathrm{PCA}-1, \mathrm{Na}, \mathrm{pH}$ and dehydrogenase in
PCA-2, and wilting point in PCA-3. Other soil properties (sand, aggregation, $\mathrm{CaCO}_{3}, \mathrm{Ca}, \mathrm{Mn}$ and urease), determined among the properties with the high additive rate of silt in PCA-4, were not covered in the MDS. In the first basic component, $63.480 \%$ of the variance was defined; others explained 8.240, 5.421 and $4.335 \%$ of variance, respectively.

Table 4. Results of principal component analysis (PCA) for soil indicators of minimum data set (MDS)

\begin{tabular}{|c|c|c|c|c|c|}
\hline $\begin{array}{c}\text { Eigenvalue } \\
\text { Percentage of variance } \% \\
\text { Total variance } \%\end{array}$ & $\begin{array}{l}\text { PCA-1 } \\
20.580 \\
63.480 \\
63.480\end{array}$ & $\begin{array}{c}\text { PCA-2 } \\
2.918 \\
8.240 \\
71.72\end{array}$ & $\begin{array}{c}\text { PCA-3 } \\
2.387 \\
5.421 \\
77.141\end{array}$ & $\begin{array}{c}\text { PCA-4 } \\
2.115 \\
4.335 \\
81.467\end{array}$ & $\begin{array}{l}\text { Total } \\
\text { correlation } \\
\text { values }\end{array}$ \\
\hline Clay & -0.769 & -0.132 & -0.111 & 0.523 & 16.89 \\
\hline Silt & -0.542 & -0.312 & -0.239 & 0.720 & 16.77 \\
\hline Sand & 0.023 & 0.609 & 0.516 & 0.204 & 6.52 \\
\hline Bulk density & -0.805 & -0.103 & 0.149 & -0.113 & 18.40 \\
\hline Penetration resistance & $-\mathbf{0 . 8 0 7}$ & -0.212 & 0.213 & -0.221 & 18.75 \\
\hline Soil porosity & 0.813 & $-0.15 \overline{5}$ & 0.070 & -0.115 & 20.03 \\
\hline Aggregation & 0.542 & 0.140 & -0.335 & 0.143 & 18.65 \\
\hline Field capacity & 0.736 & -0.145 & 0.019 & -0.062 & 19.57 \\
\hline Wilting point & 0.533 & 0.247 & 0.725 & 0.317 & 19.65 \\
\hline Available water capacity (AWC) & 0.816 & -0.317 & -0.254 & -0.262 & 16.91 \\
\hline Acidity $(\mathrm{pH})$ & -0.615 & 0.709 & 0.416 & 0.056 & 16.54 \\
\hline Electrical conductivity (EC) & 0.801 & 0.310 & -0.138 & 0.074 & 20.41 \\
\hline $\mathrm{CaCO}_{3}$ & 0.600 & -0.511 & 0.511 & 0.212 & 14.50 \\
\hline Organic matter $(\mathrm{OM})$ & 0.789 & -0.018 & -0.051 & 0.103 & 22.50 \\
\hline $\mathrm{N}$ & 0.799 & 0.040 & 0.010 & 0.110 & 21.29 \\
\hline $\mathrm{P}$ & 0.803 & 0.078 & 0.027 & -0.185 & 20.57 \\
\hline $\mathrm{K}$ & 0.815 & 0.032 & -0.246 & -0.404 & 18.18 \\
\hline $\mathrm{Ca}$ & 0.105 & 0.512 & -0.631 & 0.503 & 6.57 \\
\hline $\mathrm{Mg}$ & 0.821 & 0.123 & 0.200 & -0.186 & 19.81 \\
\hline $\mathrm{Na}$ & 0.401 & -0.699 & 0.400 & 0.400 & 10.29 \\
\hline $\mathrm{Fe}$ & 0.803 & 0.111 & 0.439 & -0.071 & 19.79 \\
\hline $\mathrm{Cu}$ & 0.645 & -0.345 & 0.021 & 0.202 & 19.54 \\
\hline $\mathrm{Zn}$ & 0.823 & -0.002 & -0.081 & 0.161 & 20.62 \\
\hline $\mathrm{Mn}$ & 0.611 & 0.234 & -0.025 & 0.216 & 17.30 \\
\hline Soil respiration $\left(\mathrm{CO}_{2}\right)$ & 0.742 & 0.112 & 0.023 & 0.017 & 18.98 \\
\hline Urease & 0.657 & 0.215 & -0.083 & -0.159 & 15.33 \\
\hline Dehydrogenase & 0.613 & -0.762 & -0.095 & 0.210 & 17.68 \\
\hline
\end{tabular}

After determining the characteristics with high additive rates in each basic component, correlations between soil indicators were analysed. Thus, among the features that showed high correlation, the feature that highly contributed to the total correlation was selected. It was considered that these selected soil quality indicators were also commonly used in many other scientific studies such as Jiang et al. (2017), Demirağ Turan et al. (2019) and Karaca et al. (2021).

A significant positive correlation $(r=0.884)$ was determined between clay and silt in texture fractions. The clay fraction is an effective property of soil quality and has high total correlation load. So, the silt indicator to be excluded from the data set. A significantly high correlation $(r=0.87,0.85)$ was determined among the physical indicators between bulk density, penetration resistance and soil porosity. Among these properties, the total correlation was determined in the highest soil porosity indicator. Soil porosity is affected as a result of changes in bulk density and penetration resistance. Hence, among these indicators, soil porosity is included in the MDS. The correlation of field capacity with the wilting point was determined as 0.87 with 0.676 AWC. The correlation between available water capacity and wilting point is relatively low $(r=0.337)$. Available water capacity specifications are not included in its data set, since they are field capacity and wilting point constants, and available water capacity has a high correlation with field capacity. Among the physical properties, clay, soil porosity and wilting point were chosen as the MDS indicators. High correlation coefficients were determined between $\mathrm{OM}$ and $\mathrm{EC}, \mathrm{pH}$ and moisture constants. The $\mathrm{OM}$, which is a very important indicator for productivity, and $\mathrm{EC}$ and acidity $(\mathrm{pH})$, which are evaluated in basic soil properties, are included in the data set.
Nitrogen displays a high correlation with $\mathrm{P}$ and $\mathrm{K}$ content among the nutrient element indicators. Due to the increased total correlation coefficient, $\mathrm{N}$ was included in the data set. As the relationship between $\mathrm{Na}$ and other nutrients is low, $\mathrm{N}$ and $\mathrm{Na}$ content among the macronutrients were included in the data set. As a result of high correlations between micronutrients, total correlation loads were examined, and the highest correlation load was determined in $\mathrm{Zn}$. Accordingly, $\mathrm{Zn}$ was chosen as the MDS indicator.

Significant relationships between $\mathrm{pH}, \mathrm{Na}$ and dehydrogenase could not be determined in PCA-2. Still, among the biological indicators, high relationships between $\mathrm{CO}_{2}$ and dehydrogenase were established. The $\mathrm{CO}_{2}$ property had high correlation with biological indicators and high total correlation; dehydrogenase was eliminated from, and $\mathrm{CO}_{2}$ was included in the data set. While wilting point was selected in PCA-3, the high relationship of silt determined in PCA-4 with clay caused it to be excluded from the data set. As a result of the PCA and examination of correlation matrices, clay, soil porosity, wilting point, $\mathrm{OM}, \mathrm{pH}, \mathrm{EC}, \mathrm{N}, \mathrm{Na}, \mathrm{Zn}$ and $\mathrm{CO}_{2}$ indicators among 27 indicators were determined as the properties selected to create a MDS.

As a result of evaluating soil properties with AHP, their weights are given in Table 5. All soil properties are indicated as hierarchy A. Firstly, physical, chemical, biological and fertility indicators were weighted generally $\left(A_{1}, A_{2}, A_{3}\right.$ and $\left.A_{4}\right)$. Then, each group was weighted according to the significance of the indicators (hierarchy C) it contains. Combine weight was determined by proportioning the weight of each soil indicator $\left(\mathrm{C}_{i}\right)$, and with the general weight of the quality indicator group it belongs to $\left(\mathrm{A}_{\mathrm{i}}\right)$. Thus, the weight of each property 
Table 5. Contribution weight of soil parameters to soil quality calculated by the analytic hierarchy process (AHP)

\begin{tabular}{|c|c|c|c|c|c|c|c|c|c|c|}
\hline \multirow[b]{2}{*}{$\begin{array}{l}\text { Hierarchy C } \\
\text { / indicator }\end{array}$} & \multicolumn{8}{|c|}{ Hierarchy A } & \multirow{2}{*}{\multicolumn{2}{|c|}{$\begin{array}{l}\text { Combine weight } \\
\qquad \sum \mathrm{A}_{\mathrm{i}} \times \mathrm{C}_{\mathrm{i}}\end{array}$}} \\
\hline & \multicolumn{2}{|l|}{$\begin{array}{c}\mathrm{A}_{1} \\
\text { physical } \\
0.3103\end{array}$} & \multicolumn{2}{|l|}{$\begin{array}{c}\mathrm{A}_{2} \\
\text { chemical } \\
0.2659\end{array}$} & \multicolumn{2}{|l|}{$\begin{array}{c}\mathrm{A}_{3} \\
\text { biological } \\
0.2018\end{array}$} & \multicolumn{2}{|l|}{$\begin{array}{c}\mathrm{A}_{4} \\
\text { fertility } \\
0.2222 \\
\end{array}$} & & \\
\hline Clay & $0.1613^{*}$ & $0.3643^{* *}$ & & & & & & & $0.0501^{*}$ & $0.1130^{* *}$ \\
\hline Silt & 0.1121 & & & & & & & & 0.0348 & \\
\hline Sand & 0.1413 & & & & & & & & 0.0438 & \\
\hline Bulk density & 0.1003 & & & & & & & & 0.0311 & \\
\hline Field capacity & 0.0896 & & & & & & & & 0.0278 & \\
\hline Wilting point & 0.0896 & 0.3367 & & & & & & & 0.0278 & 0.1045 \\
\hline Available water capacity (AWC) & 0.0916 & & & & & & & & 0.0284 & \\
\hline Aggregation & 0.0668 & & & & & & & & 0.0207 & \\
\hline Penetration resistance & 0.0648 & & & & & & & & 0.0201 & \\
\hline Soil porosity & 0.0826 & 0.2290 & & & & & & & 0.0256 & 0.0928 \\
\hline Organic matter (OM) & & & $0.5536 *$ & $0.5035^{* *}$ & & & & & 0.1472 & 0.1339 \\
\hline Electrical conductivity (EC) & & & 0.2223 & 0.2523 & & & & & 0.0591 & 0.0671 \\
\hline Acidity $(\mathrm{pH})$ & & & 0.1472 & 0.2442 & & & & & 0.0391 & 0.0649 \\
\hline $\mathrm{CaCO}$ & & & 0.0769 & & & & & & 0.0204 & \\
\hline Soil respiration $(\mathrm{CO})$ & & & & & $0.4052 *$ & $1.00 * *$ & & & 0.0818 & 0.2018 \\
\hline Urease & & & & & 0.3064 & & & & 0.0618 & \\
\hline Dehydrogenase & & & & & 0.2884 & & & & 0.0582 & \\
\hline $\mathrm{N}$ & & & & & & & $0.2601 *$ & $0.4680 * *$ & 0.0578 & 0.1039 \\
\hline $\mathrm{P}$ & & & & & & & 0.2009 & & 0.0446 & \\
\hline $\mathrm{K}$ & & & & & & & 0.1629 & & 0.0362 & \\
\hline $\mathrm{Ca}$ & & & & & & & 0.1029 & & 0.0229 & \\
\hline $\mathrm{Mg}$ & & & & & & & 0.0816 & & 0.0181 & \\
\hline $\mathrm{Na}$ & & & & & & & 0.0584 & 0.2780 & 0.0130 & 0.0617 \\
\hline $\mathrm{Mn}$ & & & & & & & 0.0467 & & 0.0104 & \\
\hline $\mathrm{Fe}$ & & & & & & & 0.0361 & & 0.0080 & \\
\hline $\mathrm{Cu}$ & & & & & & & 0.0264 & & 0.0059 & \\
\hline $\mathrm{Zn}$ & & & & & & & 0.0240 & 0.2540 & 0.0053 & 0.0564 \\
\hline$\Sigma$ & 1.00 & 1.00 & 1.00 & 1.00 & 1.00 & 1.00 & 1.00 & 1.00 & 1.00 & 1.00 \\
\hline
\end{tabular}

* - weighting values in the first column for total data set (TDS), ** - weighting values in the second column for minimum data set (MDS); $A_{i}-A_{1}, A_{2}, A_{3}, A_{4}, C_{i}$ - weight indicators

was determined within the indicator group (physical, chemical, biological and fertility) it belongs to.

The highest value $(0.3103)$ was determined for physical parameters (hierarchy $A_{1}$ ), while the lowest value $(0.2018)$ was found for soil biological (hierarchy $A_{3}$ ) properties. The highest contribution from the indicators in each hierarchy $\mathrm{A}_{1}, \mathrm{~A}_{2}, \mathrm{~A}_{3}$ and $\mathrm{A}_{4}$ was determined as clay percentage $(0.1613)$, OMM $(0.5536), \mathrm{CO}_{2}(0.4052)$ and $\mathrm{N}(0.2601)$, respectively.

Although the chemical properties and nutrient contents come to mind first in soil fertility and quality, the absence of soil's physical structure at an optimum level in terms of chemical content significantly affects productivity and plant growth. Among the physical indicators, the highest weight was evaluated for the texture fractions. The effect of sand, silt and clay on the water and nutrient retention properties significantly affect productivity. The high rate of these features' contribution was compatible with other studies (Senol et al., 2019). After the texture fractions, the volume weight indicator was weighted higher than the other properties. The adverse effect of water retention and infiltration due to the increase of this feature, which is an indicator of both compression and soil porosity, reveal that it is a feature that contributes significantly to yield and quality.

Among the chemical indicators, the rate of contribution of organic material was determined as the highest. Many studies (Olorunfemi et al., 2018; Volungevičius et al., 2019; Alaboz, Öz, 2020) have shown that the decomposition of OM positively affects physical conditions and chemical properties of soil. Again, among biological indicators, one of the fundamental biological activity indicators soil respiration $\left(\mathrm{CO}_{2}\right)$ has the highest additive rate (weight 1.00). The contribution rates of macronutrients in nutrients are at higher levels than micronutrients. The increased need of the plant and its deficiency cause significant changes in productivity and quality parameters, and it is the reason for the determined high contribution rate. In the weighting of the 10 indicators selected by creating a MDS, one of the chemical indicators clay $(0.3643)$, OM $(0.5035)$ and $\mathrm{N}$ $(0.4680)$ content among the nutrients were determined to have the highest additive ratio. In determining the contribution rates, evaluations were made considering the priorities determined for the entire data set.

The SQI values and product yields obtained for both data sets due to evaluating the scores obtained from AHP results and standard scoring functions with the linear combination technique are indicated in Table 6 .

The $\mathrm{SQI}_{\mathrm{TDS}}, \mathrm{SQI}_{\mathrm{MDS}}$ and the yield values showed a significant change $(P<0.01)$ depending on the biogas waste application. SQI values obtained with both data sets are classified as "low" in II class quality in B0 (control) soil. In contrast, 10 and $20 \mathrm{t} \mathrm{ha}^{-1} \mathrm{BW}$ and "moderate" 30 and $40 \mathrm{t} \mathrm{ha}^{-1} \mathrm{BW}$ soils are classified as IV class "high". The highest value in $\mathrm{SQI}_{\mathrm{TDS}}$ obtained by using 27 indicators was at the $40 \mathrm{t} \mathrm{ha}^{-1} \mathrm{BW}$, while with $\mathrm{SQI}_{\mathrm{MDS}}$ it was determined at $30 \mathrm{t} \mathrm{ha}^{-1} \mathrm{BW}$. In addition, 30 and $40 \mathrm{tha}^{-1} \mathrm{BW}$ treatments were statistically similar.

For both data sets, soil quality compared to $0 \mathrm{t} \mathrm{ha}^{-1} \mathrm{BW}$ showed an increase of approximately $10-15$, $30-35,45-50$ and 50-60\%, respectively, depending on the applications. When the plant yield was examined, barley yield, which was $4940 \mathrm{~kg} \mathrm{ha}^{-1}$ at the $0 \mathrm{t} \mathrm{ha}^{-1} \mathrm{BW}$, showed a significant increase $(P<0.01)$ depending on the biogas waste application. Compared to the $0 \mathrm{t} \mathrm{ha}^{-1}$ $\mathrm{BW}$, depending on the increase at B1, B2, B3 and B4 applications, an increase in yield of 9.71, 17.20, 35.62 and $34.21 \%$, respectively, was determined. Abubaker et al. (2012) reported that an increase in the wheat yield was determined compared to the $0 \mathrm{t} \mathrm{ha}^{-1} \mathrm{BW}$. During the breakdown of organic fertiliser, $\mathrm{N}$ present in the soil is consumed by microorganisms. Therefore, $\mathrm{N}$ fertilisers together with organic materials will contribute to the plants' benefit more effectively from fertilisers.

In this study, basic fertilisation was applied to all applications together with the biogas waste application. No significant differences were determined between 30 and $40 \mathrm{t} \mathrm{ha}^{-1} \mathrm{BW}$ in the effect of the applications on yield. While significant differences were determined between 30 and $40 \mathrm{t} \mathrm{ha}^{-1} \mathrm{BW}$ in SQI $\mathrm{TDS}$, there was no substantial change with SQI $\mathrm{SIS}_{\mathrm{S}}$ depending on the application of 30 and $40 \mathrm{t} \mathrm{ha}^{-1} \mathrm{BW}$. With SQI ${ }_{\mathrm{MDS}}$ productivity showed statistically similar changes depending on applications. 
Table 6. Effect of biogas waste application on soil quality and barley yield

\begin{tabular}{|c|c|c|c|c|c|c|c|c|}
\hline & $\mathrm{SQI}_{\mathrm{TDS}}$ & $\mathrm{SQI}_{\mathrm{MDS}}$ & $\begin{array}{c}\text { Yield (Y) } \\
\mathrm{kg} \mathrm{ha}^{-1}\end{array}$ & Prediction equation & $R^{2^{* * *}}$ & $R^{2 * *}$ & RMSE & AIC \\
\hline $\begin{array}{l}\mathrm{B} 0 \\
\mathrm{~B} 1\end{array}$ & $\begin{array}{l}0.468 \mathrm{e}^{*} \\
0.519 \mathrm{~d}\end{array}$ & $\begin{array}{c}0.473 \mathrm{D}^{*} \\
0.547 \mathrm{C}\end{array}$ & $\begin{array}{c}4940 \mathrm{~d}^{*} \\
5420 \mathrm{c}\end{array}$ & $\mathrm{Y}_{\mathrm{SQITDS}}=2289.71+5953.14 \mathrm{SQI}_{\mathrm{TDS}}$ & 0.80 & 0.87 & 311.3 & 516.30 \\
\hline $\begin{array}{l}\text { B2 } \\
\text { B3 } \\
\text { B4 }\end{array}$ & $\begin{array}{c}0.6345 \mathrm{c} \\
0.692 \mathrm{~b} \\
0.711 \mathrm{a}\end{array}$ & $\begin{array}{l}0.625 \mathrm{~B} \\
0.705 \mathrm{~A} \\
0.703 \mathrm{~A}\end{array}$ & $\begin{array}{l}5790 \mathrm{~b} \\
6700 \mathrm{a} \\
6630 \mathrm{a}\end{array}$ & $\mathrm{Y}_{\mathrm{SQIMDS}}=1821.62+6773.06 \mathrm{SQI}_{\mathrm{MDS}}$ & 0.90 & 0.88 & 241.2 & 444.53 \\
\hline
\end{tabular}

Note. SQI ${ }_{\mathrm{TDS}}$ - soil quality index, obtained with the total data set, $\mathrm{SQI} \mathrm{MDS}-$ obtained with the minimum data set; * - differences significant at $p<0.01$ level between values that are not represented by the same letter; ** - obtained $R^{2}$ when creating stage of model, $* * *$ - obtained $R^{2}$ when testing stage of model; RMSE - root mean square error; AIC - Akaike information criterion.

General regression equations for estimating productivity depending on the difference in soil quality are presented in Table 6 . With the general regression method, $R^{2}$ in the yield estimation equations from $\mathrm{SQI}_{\mathrm{TDS}}$ and $\mathrm{SQI}_{\mathrm{MDS}}$ were determined at 0.80 and 0.90 levels, respectively. The highest predictive accuracy was

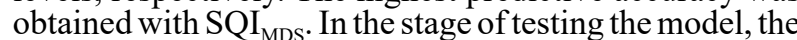
$R^{2} \mathrm{~S}$ obtained are relatively close to each other $(0.87$ and $0.88)$, while the lowest RMSE and AIC values $(241.2 \mathrm{~kg}$ and 444.53) were obtained in the model with SQI $\mathrm{MDS}^{\text {. }}$ Although the $R^{2} \mathrm{~s}$ are similar in the models, the low levels of RMSE and AIC is an indication that the validity of the model, in which SQI ${ }_{\mathrm{MDS}}$ is used as an independent variable is higher. The high level of $R^{2}$ among the parameters used in the validation of the models and the low levels of other evaluation criteria is seen as an indicator of the success of the model (Alaboz et al., 2021).
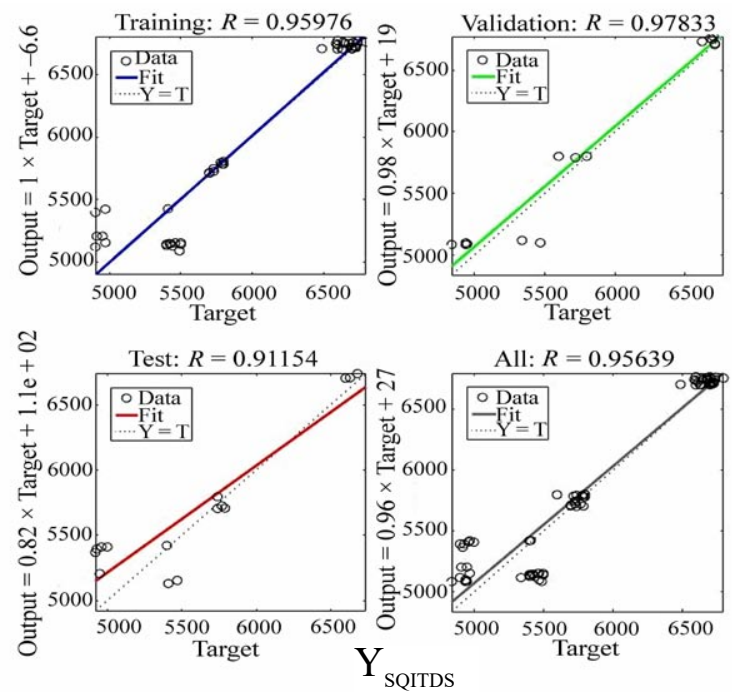

The AIC value cannot be directly interpreted. For a model, it does not provide information about whether - the model-data fit is good or bad. It offers the opportunity to compare, which of the compared models is more suitable for the data. It is known that a data set with a low AIC value is more compatible with the model (Brewer et al., 2016). By analysing the regression equations obtained, it was revealed that the estimation of the value in the yield of the crop could be successfully realized with the soil properties determined in the MDS and the SQI. Except for general regression equations, $R$ values for yield estimation results with artificial neural networks (ANN) with 1:10:1 network architecture are shown in Figure 3.

While $R^{2}$ values obtained from training, validation and testing in yield estimation from $\mathrm{SQI}$ $\left(\mathrm{Y}_{\mathrm{SQITDS}}\right)$ were $0.92,0.95$ and 0.83 , the said values were
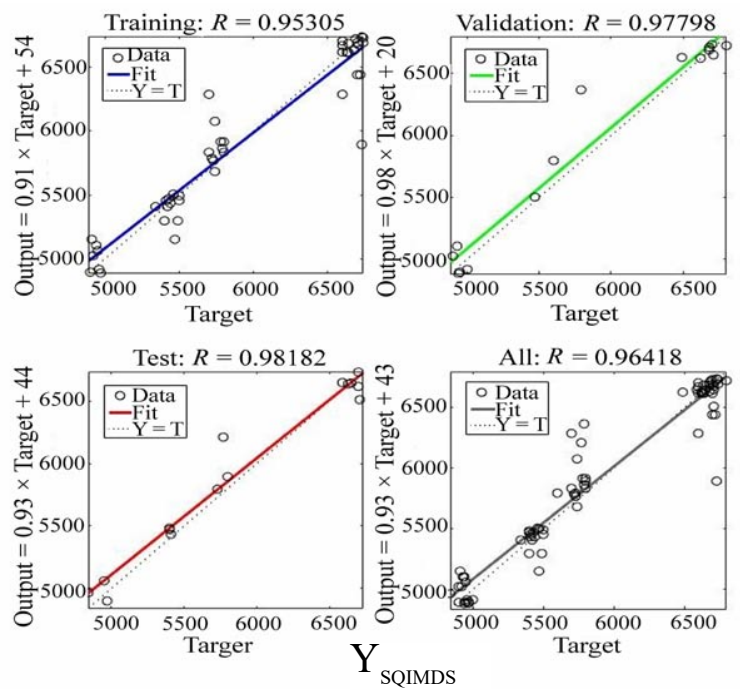

Figure 3. Barley yield (Y) prediction with artificial neural networks (ANN)

determined as $0.90,0.95$ and 0.96 in $\mathrm{Y}_{\mathrm{SOIMDS}}$ respectively. In general, $\mathrm{Y}_{\text {SOITDS }}$ can be predicted with $91 \%$, and $\mathrm{Y}_{\text {SOIMDS }}$ - with $92 \%$ accuracy in estimation with ANN. The R's obtained in training and validation stages in both data sets were found to be quite similar to each other. However, the existence of deviations from the linear curve in the estimation of $\mathrm{Y}_{\mathrm{SQITDS}}$ during the test phase caused the $R$ to be lower. Besides, while RMSE and AIC values were $227.8 \mathrm{~kg}$ and 471.49 for $Y_{\text {SQITDS }}$, the said values were 125.5 $\mathrm{kg}$ and 359.58 for $Y_{\text {SOIMDS }}$, respectively. The lowest RMSE and AIC values were determined in $\mathrm{Y}_{\text {SQIMDs }}$ similar to $R^{2}$. Compared to the general regression results, the yield was estimated with higher accuracy with ANN in the models' evaluation and test phase. The RMSE value is the deviating mean error of the predicted value, while AIC shows the overall probability of error for the entire data set.

The OM with colloid property positively affects soil quality, as it forms clay-humus complexes, increases available water capacity, provides an energy source to microorganisms and reveals nutrients that plants can benefit from decomposition (Plaster, 2013). As shown in this study, an expected result is increasing soil quality together with the soil structure's organic material, which covers the whole of physical, chemical and biological processes. However, it is a critical approach to determine and estimate how this affects crop yield and validate it with field trials. This study also revealed that the MDS methods could be used successfully in soil quality studies and exhibit very similar results to the entire data set. Şeker et al. (2017) used different scoring functions to predict soil quality by creating a MDS and stated that PCA is a suitable quality evaluation method.

\section{Conclusion}

This study investigated the effect of different amounts of biogas waste (BW) application on soil quality and crop yield. As a result of evaluating the minimum data set (MDS) formed with 27 physical, chemical and biological soil indicators and 10 soil indicators selected by principal component analysis (PCA), the yield values were associated with the soil quality index (SQI). The productivity estimates were made from a SQI with multiple linear regression and artificial neural networks (ANN). Indicators in the MDS were determined as clay, soil porosity, wilting point, organic matter (OM), soil 
acidity $(\mathrm{pH})$, electrical conductivity $(\mathrm{EC})$ and $\mathrm{N}, \mathrm{Na}, \mathrm{Zn}$ and $\mathrm{CO}_{2}$ content. At the $0 \mathrm{t} \mathrm{ha}^{-1} \mathrm{BW}$, when soil quality was determined as "low" (II class), soils quality was classified as "moderate" and "high" (III and IV class). As a result of the experiment, the optimum yield value $\left(6700 \mathrm{~kg} \mathrm{ha}^{-1}\right)$ was obtained at the $30 \mathrm{t} \mathrm{ha}^{-1} \mathrm{BW}$. The results obtained with $\mathrm{SQI}_{\mathrm{MDS}}$ in two data sets were found to be similar in yield. The results of the experiment concluded that soil quality evaluation could be successfully estimated by creating a MDS. The yield with ANN was estimated with higher coefficient of determination $\left(R^{2}\right)(0.92)$ and lower root mean square error (RMSE) $(125.5 \mathrm{~kg})$ and Akaike information criterion (AIC) (359.58) values than the general regression equation. When assessing soil quality studies, it was found that machine learning algorithms can be learned using the necessary algorithms and formulations from each data given in the computer environment instead of linear equations. Machine learning algorithms can be used to reach the decision-making level.

This study demonstrated that barley yield can be successfully estimated from the soil quality index determined by creating a minimum data set (SQI ${ }_{\mathrm{MDS}}$ ). While investigating the effect of organic material on soil or yield in many studies, it has been determined that the organic material applied in this experiment can increase the soil quality by $10-55 \%$ depending on the change in application doses. This increase will lead to an improvement in product yield by approximately $10-35 \%$. It has been estimated with high accuracy with change estimation models. It is thought that with the forecasting models created the producers will significantly reduce the workforce and provide economic income.

It is suggested that future studies should evaluate the obtained estimation models and the indicators selected in the MDS with different organic materials for soils with similar ecosystems. As a result, biogas production and use are a promising application to reduce humanity's negative impacts on the environment and the use of fossil fuels. Researchers should consider the potential for significant unused biogas production waste and increase research into the use of biogas.

Received 10122020 Accepted 11052021

\section{References}

Abubaker J., Risberg K., Pell M. 2012. Biogas residues as fertilisers - effects on wheat growth and soil microbial activities. Annlied Fnergy, 99: 126-134. https://doi.org/10.1016/j.apenergy.2012.04.050

Ai Y.-J., Li F.-P., Gu H.-H., Chi X.-J., Yuan X.-T., Han D.-Y. 2020. Combined effects of green manure returning and addition of sewage sludge compost on plant growth and microorganism communities in gold tailings. Environmental Science and Pollution Research International, 27: 31686 31698. https://doi.org/10.1007/s11356-020-09118-z

Alaboz P., Demir S., Dengiz O. 2021. Assessment of various pedotransfer functions for the prediction of the dry bulk density of cultivated soils in a semiarid environment. Communications in Soil Science and Plant Analvsis, 52 (7) 724-742. https://doi.org/10.1080/00103624.2020.1869760

Alaboz P., Öz H. 2020. Effects of biochar and solarization applications on some soil physical properties. Anadolu Iournal of Agricultural Sciences, 35 (2): 208-214 (in Turkish) https://doi.org/10.7161/omuanajas.697458

Beyer L., Waehendorf C., Elsner D. C., Knabe R. 1993. Suitability of dehydrogenase activity assay as an index of soil biolngical activity. Binlogy and Fertility of Soils, 16: 52-56. https://doi.org/10.1007/BF00336515

Bouyoucos G. J. 1951. A recalibration of the hydrometer method for making mechanical analysis of soils. Agronomy Journal, 42 (9): 438-443. https://doi.org/10.2134/agronj1951.00021962004300090005x

Brewer M. J., Butler A., Cooksley S. L. 2016. The relative performance of AIC, AICC and BIC in the presence of unobserved heterogeneity. Methods in Ecology and Fvolution. 7 (6): 679-692

https://doi.org/10.1111/2041-210X.12541
Bünemann E. K., Bongiorno G., Bai Z., Creamer R. E., De Deyn G., de Goede R., Fleskens L., Geissen V., Kuyper T. V., Mäder P., Pulleman M., Sukkel W., van Groenigen J. W., Brussaard L. 2018. Soil quality - a critical review. Soil Biology and Rinchemistry $120 \cdot 105-125$ https://doi.org/10.1016/j.soilbio.2018.01.030

Burt R. (ed.). 2014. Kellogg soil survey laboratory methods manual. Soil Survey Investigations Report No. 42, version 5.0. USDA.

Carter M. R., Gregorich E. G. (eds.). 2007. Soil Sampling and Methods of Analysis ( $7^{\text {nd }}$ ed ) Canadian Society of Soil Science. https://doi.org/10.1201/9781420005271

Demirağ Turan I., Dengiz U. 2017. Erosion risk prediction using multi-criteria assessment in Ankara Güvenç basin. Journal of Agricultural Sciences, 23 (3): 285-297 (in Turkish). https://doi.org/10.15832/ankutbd.447600

Demirağ I uran I., Dengiz O., Özkan B. 2019. Spatial assessment and mapping of soil quality index for desertification in the semiarid terrestrial ecosystem using MCDM in interval type2 fuzzy environment Comnuters and Flectronics in A griculture, 164: 104933. https://doi.org/10.1016/j.compag.2019.104933

Dengiz O. 2020. Soil quality index for paddy fields based on standard scoring functions and weight allocation method. A rchives of A gronnmy and Snil Science, 66 (3): 301-315. https://doi.org/10.1080/03650340.2019.1610880

Doran J. W., Parkin I. B. 1994. Detining and assessing soil quality. Doran J. W. et al. (eds). Defining Soil Quality for a Sustainable Environment. Soil Science Society of America Snecial Publication, vol 35, n 1-71 https://doi.org/10.2136/sssaspecpub35.c1

Ekberli i., Dengiz O. 2016. Determination of regression relationship between physico-chemical properties and thermal diffusion coefficient of some Inceptisol and Entisol sub groun snils Inurnal of Snil Water 5 (?) 1-10 (in Turkish). https://doi.org/10.21657/topraksu.268957

FAO. 2006. Plant nutrition for tood security. A guide for integrated nutrient management. FAO Fertilizer and Plant Nutrition Bulletin No. 16.

Ghorbani M. A., Shamshirband S., Haghi D. Z., Azani A., Bonakdari H., Ebtehaj I. 2017. Application of firefly algorithmbased support vector machines for prediction of field capacity and permanent wilting noint Soil and Tillage Research, 172: 32-38. https://doi.org/10.1016/j.still.2017.04.009

Gliński J. et al. (eds). 7111 Hincyclonedia of Agronhysics. Springer, p. 264-267. https://doi.org/10.1007/978-90-481-3585-1

Graupe D. 2013. Principles of Artiticial Neural Networks (3 ${ }^{\text {rd }}$ ed ) World Srientific Puhlishing, $384 \mathrm{p}$. https://doi.org/10.1142/8868

Hazelton P., Murphy B. 2016. Interpreting soil test results: What do all the numbers mean? ( $3^{\text {rd }}$ ed ) C.SIRO Publishing, p. 95-107. https://doi.org/10.1071/9781486303977

Hofmann E. D., Hottmann (i. G. 1966. Die Bestimmung der Biologischen Tätigkeit in Böden Mit Enzymmethoden. Advances in Enzymology and Related Areas of Molecular Rinloov 28. 365-390 (in German) https://doi.org/10.1002/9780470122730.ch6

Hurnı H., Giger M., Linıger H., Studer K. M., Messerli P., Portner B., Schwilch G., Wolfgramm B., Breu T. 2015. Soils, agriculture and food security: the interplay between ecosystem functioning and human well-being. Current Oninion in Fnvirnnmental Sustainahility 15: 25-34. https://doi.org/10.1016/j.cosust.2015.07.009

Isermayer H. 1952. Eine einfache Methode zur Bestimmung der Pflanzenatmung un der Karbonate in Boden. Die Zeitschrift für Pflanzenernährıng und Bodenkınde, 56: 76-28 (in German). https://doi.org/10.1002/jpln.19520560107

Jiang L., Han G, Lan Y., Liu S., Gao J., Yang X., Meng J., Chen W. 2017. Corn con biochar increasing soil culturable bacterial abundance without enhancing their capacities in utilizing carbon source in Biolog Eco-plates. Journal of Integrative A griculture, $16(3) \cdot 713-774$ https://doi.org/10.1016/S2095-3119(16)61338-2

Karaca S., Dengiz U., Demirağ 'luran I.., Özkan B., Dedeoğlu M., Gülser F., Sargin B., Demirkaya S., Ay A. 2021. An assessment of pasture soils quality based on multi-indicator weighting approaches in semi-arid ennsvstem Fonlnoical Indicators, 121: 107001. https://doi.org/10.1016/j.ecolind.2020.107001

Masto R. E., Chhonkar P. K., Singh D., Patra A. K. 2007. Soil quality response to long-term nutrient and crop management on a semi-arid Inceptisol. Agriculture, Ecosystems and Fnvirnnment $118(1-4) \cdot 130-14$ ) https://doi.org/10.1016/j.agee.2006.05.008 
Müjdeci M., Demircioğlu A. C., Alaboz P. 2020. The effects of farmyard manure and green manure applications on some soil physical properties. YYU Journal of Agricultural Sciences, 30 (1): 9-17. https://doi.org/10.29133/yyutbd.628921

Mukherjee A., Lai K. Zúi4. Comparison of soil quaiity index using three methods. PI $n$ S ONE, 9 (8): e105981. https://doi.org/10.1371/journal.pone.0105981

Nesic L., Belic M., Savin L., Ciric V., Stefanovcic M., Manojlovic M. 2014. Effect of organic production on soil structure. Bulgarian Journal of Agricultural Science, 20 (5): $1168-1174$.

Olorunfemi I. E., Fasinmirin J. T., Akinola F. F. 2018. Soil physico-chemical properties and fertility status of longterm land use and cover changes: a case study in Fores vegetative zone of Nigeria. Furasian Iournal of Soil Science, 7 (2): 133-150. https://doi.org/10.18393/ejss.366168

Plaster E. J. 2013. Soil Science and Management ( $6^{\text {th }}$ ed.). Cengage Learning Publishing, India, $520 \mathrm{p}$.

Richards L. A. (ed.). 2012. Diagnosis and Improvement of Saline and Alkali Soils. Scientific Publishers, 160 p.

Saaty T. L. 2001. Fundamentals of the analytic hierarchy process. Schmoldt D. L. et al. (eds). The Analytic Hierarchy Process in Natural Resource and Environmental Decision Making. Vol 3. Managing Forest Erosvstems, p. 15-35. https://doi.org/10.1007/978-94-015-9799-9 2

Şeker C., Üzaytekin H. H., Negis H., Gumus i., Dedeoğlu M. Atmaca E., Karaca Ü. 2017. Identification of regional soil quality factors and indicators: a case study on an alluvial nlain (central Turkev). Solid Farth 8 (3): 583-595. https://doi.org/10.5194/se-8-583-2017

Şenol H., Alaboz P., Demir S., Dengiz U. 2020. Computational intelligence applied to soil quality index using GIS and geostatistical approaches in semiarid ecosystem. Arabian Inurnal of Gensciences 13(73) : 1-70 https://doi.org/10.1007/s12517-020-06214-9

Şenoi H., Dengiz U., Alaboz P. 2019. Determination of spatial variability of soil quality index based on multi criteria decision analysis. $10^{\text {th }}$ international soil congress Successful Transformation toward Land Degradation Neutrality: Future Perspective. Ankara, Turkey, p. 70-74. http://www. toprak.org.tr/files/Proceeding-Soil-2019.pdf
Shi T., Wang J., Liu H., Wu G. 2015. Estimating leaf nitrogen concentration in heterogeneous crop plants from hyperspectral reflectance. International Journal of Remote Sensing $36(18) \cdot 465)-4667$ https://doi.org/10.1080/01431161.2015.1088676

Tabataba1 M. A., Bremner J. M. 19/2. Assay of urease activity in soils Soil Rinlngy and Rinchemistry 4 (4): 479-487. https://doi.org/10.1016/0038-0717(72)90064-8

Tavantı K. F. K., Fredd1 U. S., Iavantı I. K., Rigotti A., Magalhães W. A. 2019. Pedofunctions applied to the least limiting water range to estimate soil water content at snecific notentials. Fngenharia Agrínola, 39 (4): 444 456 httrs $: /$ doi. org/10.1590/1809-4430-eng.agric.v39n4p444-456/2019

Tongsir1 $\mathrm{P}$. Iseng $\mathrm{W}-\mathrm{Y}$, shen $\mathrm{Y}$, La1 $\mathrm{H}, \mathrm{Y}, 202 \mathrm{U}$. Comparison of soil properties and organic components in infusions according to different aerial appearances of tea plantations in central Taiwan Sustainahility 12 (11): 4384. https://doi.org/10.3390/su12114384

Van Wambeke A. K. 2000. The Newhall Simulation Model for estimating soil moisture and temperature regimes. Department of Crop and Soil Sciences. Cornell University, USA, 9 p.

Volungevičius J., Feiza V., Amalevičiūtè-Volungè K., Liaudanskienè I., Šlepetienè A., Kuncevičius A., Vengalis R., Vèlius G., Prapiestienè R., Poškienè J. 2019. Transformations of different soils under natural and anthropogenized land management 7emdirhyste-Agriculture, 106 (1): 3-14. https://doi.org/10.13080/z-a.2019.106.001

Wang W., Liu J., Zhao B., Zhang J., Li X., Yan Y. 2015. Critical evaluation of particle size distribution models using soil data obtained with a lacer diffraction method PI nS ONF 10 (4): e0125048. https://doi.org/10.1371/journal.pone.0125048

Watzinger A. 2015. Microbial phospholipid biomarkers and stable isotope methods help reveal soil functions. Soil Rinlogy and Rinchemistry 86. 98-107. https://doi.org/10.1016/j.soilbio.2015.03.019

Yamaç S. S., Șeker C., Negiș H. 2020. Evaluation of machine learning methods to predict soil moisture constants with different combinations of soil input data for calcareous soils in a semi arid area Aoricultural Water Management, 234: 106121. https://doi.org/10.1016/j.agwat.2020.106121

\title{
Miežių derliaus panaudojus biodujų gamybos atliekas vertinimas, taikant dirbtinių neuroninių tinklų metodą, integruotą su dirvožemio kokybès indeksu
}

\author{
P. Alaboz ${ }^{1}$, O. Dengiz², S. Demir ${ }^{1}$
}

${ }^{1}$ Ispartos taikomujjų mokslų universiteto Žemès ūkio fakultetas, Turkija

${ }^{2}$ Ondokuz Mayıs universiteto Žemès ūkio fakultetas, Turkija

\section{Santrauka}

Siekiant patenkinti didejjantį maisto poreikį, itin svarbu įvertinti dirvožemio kokybę ir pasèlių derlingumą. Tyrimo metu analizuota ir prognozuota biodujų gamybos atliekų įtaka dirvožemio kokybei ir augalų derlingumui. Tirtas

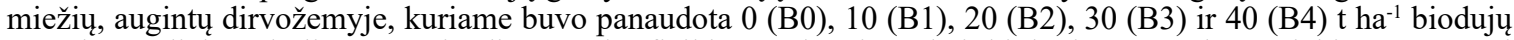
gamybos atliekų, derlingumas ir dirvožemio fizikinès, cheminès bei biologinès savybès. Siekiant nustatyti dirvožemio kokybės indeksą, taikytas analitinis hierarchijos procesas ir tiesinio derinio metodas; 27 dirvožemio rodikliai ir $10 \mathrm{kitu}$ rodiklių buvo vertinti atskirai pagal minimalų duomenų rinkinį, sukurtą taikant pagrindinių komponenčių analizę (PCA). Dirvožemio kokybės indekso reikšmių ir miežių derlingumo ryšys ịvertintas taikant dirbtiniu neuroninių tinklu ( $A N N)$ metodą ir bendrąsias regresijos lygtis bei Levenbergo-Marquardto algoritmus. Dirvožemio kokybè, kuri buvo II klasès, panaudojus $0 \mathrm{t} \mathrm{ha}^{-1}$ (kontrolinis variantas) biodujų gamybos atliekų taikant abu duomenų rinkinius buvo apibūdinta kaip III ir IV kokybès klasès. Nors miežių derlingumo padidèjimas buvo susijęs su dirvožemio kokybės indekso vertèmis, gautomis taikant dirvožemio kokybės indekso minimalų duomenu rinkinį, optimalus derlingumas gautas panaudojus $30 \mathrm{tha}^{-1}$ biodujų gamybos atliekų - jis padidejo 35,62\%, palyginti su $0 \mathrm{t} \mathrm{ha}^{-1}$ biodujų gamybos atliekų.

Abiejų duomenu rinkinių miežių derlingumo îvertinimo pagal dirvožemio kokybès indeksą determinacijos koeficientas $\left(R^{2}\right)$ taikant bendrają regresiją buvo 0,87-0,88 prognozavimo tikslumo. Taikant $A N N$ metodą nustatytos $0,91-0,92$ reikšmès. Tarp vertinimo metodų didžiausias $R^{2}$, maža vidutinè kvadratinè paklaida $(R M S E)(125,5 \mathrm{~kg})$ ir Akaikès informacinis kriterijus $(A I C)(359,58)$ nustatyti taikant $A N N$.

Atlikus eksperimentą padaryta išvada, kad biodujų gamybos atliekų panaudojimas gerina dirvožemio kokybę ir didina augalų derlingumą. Minimalų duomenų rinkinį galima sẻkmingai pritaikyti dirvožemio kokybei nustatyti, o taikant $A N N$, pagal dirvožemio kokybę galima tiksliai prognozuoti augalų derlingumą.

Reikšminiai žodžiai: Akaikès informacinis kriterijus, analitinis hierarchinis procesas, biodujų gamybos atliekos, dirbtinių neuronų tinklai, dirvožemio kokybė, minimalus duomenų rinkinys. 